\title{
Congenital rubella syndrome as a model for Type 1 (insulin-dependent) diabetes mellitus: increased prevalence of islet cell surface antibodies
}

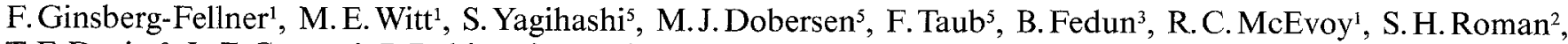 \\ T.F.Davies ${ }^{2}$, L.Z. Cooper ${ }^{3}$, P. Rubinstein ${ }^{4}$, and A. L. Notkins ${ }^{5}$ \\ ${ }^{1}$ Division of Pediatric Endocrinology and Metabolism Department of Pediatrics, ${ }^{2}$ Division of Endocrinology, Department of Medicine, \\ Mount Sinai School of Medicine; ${ }^{3}$ Department of Pediatrics, Roosevelt-St. Luke's Hospital, New York; ${ }^{4}$ Laboratory of Immunogenetics, \\ Lindsley F. Kimball Research Institute, New York Blood Center, New York; and ${ }^{5}$ Laboratory of Oral Medicine, \\ National Institutes of Health, Bethesda, Maryland, USA
}

\begin{abstract}
Summary. An increased prevalence of Type 1 (insulin-dependent) diabetes has been reported in patients with congenital rubella. Rubella virus multiplies in the pancreas, and we have hypothesized that studies of children with congenital rubella would be of great importance in following the development of Type 1 diabetes in a defined, susceptible population. Two hundred and forty-one children with congenital rubella (mean age $17.4 \pm 0.3$ years; $65 \%$ black and hispanic) have been evaluated, 30 of whom already have diabetes and 17 of whom have borderline glucose tolerance. In these latter two groups, HLA-DR3 is significantly increased and HLA-DR2 significantly decreased. Pancreatic islet cell cytotoxic surface antibodies are found in $20 \%$ of the total congenital rubella population, including in more than $50 \%$ in the time period before they develop diabetes and are not related to any specific
\end{abstract}

HLA type. In addition, anti-microsomal and anti-thyroglobulin antibodies are found in $34 \%$ of this population. The data demonstrate that Type 1 diabetes developing in congenital rubella patients has the genetic and immunological features of classical Type 1 diabetes, namely the presence of HLA-DR3, the absence of HLA-DR2, islet cell surface antibodies before decompensation and an increased prevalence of anti-thyroid antibodies. Patients with non-diabetic congenital rubella represent an easily identifiable group in whom other immunological factors associated with Type 1 diabetes can be elucidated and possibly modified.

Key words: Type 1 diabetes, congenital rubella, islet cell surface antibodies, viral trigger.
In 1949 Hay first reported the association of congenital rubella and diabetes mellitus [1]. Subsequently Menser et al. have reported a $40 \%$ prevalence of diabetes in a large group of patients with congenital rubella born in New South Wales and followed since 1942 [2]. Nance's group [3] found a $13 \%$ prevalence of abnormalities in glucose and insulin responses in 101 students at the Maryland and Virginia Schools for the deaf, a large proportion of whom were thought to be deaf secondary to congenital rubella. Since rubella virus multiplies and can cause lesions in the pancreas [4], the subsequent development of diabetes is not surprising. In addition, since it has been hypothesized that viruses can infect pancreatic $\beta$ cells in genetically susceptible individuals leading to the production of antibodies against the $\beta$ cells [5], we designed our protocol to study longitudinally the genetic, immunological and metabolic features of a large cohort of patients known to have had congenital rubella. Such studies could help define the natural history and pathogenesis of diabetes mellitus if similar genetic and immunological features could be demon- strated in this group as in classical Type 1 diabetic patients.

\section{Subjects and methods}

\section{Patient population}

All 242 patients (mean age $17.4 \pm 0.3$ years; $65 \%$ black and hispanic; $52 \%$ males) studied to date are either being followed at the Developmental Disabilities Center, St Luke's Roosevelt Hospital or at the Pediatric Diabetes Clinic, Mount Sinai Hospital, New York. They all have stigmata of the congenital rubella syndrome, including different combinations of mental retardation and microcephaly, deafness, cataracts, congenital heart disease and chorioretinopathy. The diagnosis of congenital rubella was, however, based on one or more of three criteria: (1) isolation of rubella virus in the throat, urine and/or cerebral spinal fluid of the newborn; (2) confirmation by detection of rubella specific IgM haemagglutination inhibition (HI antibody) in sera from newborns or persistence of rubella specific IgG haemagglutination antibody on serial specimens beyond the first year of life; (3) presence of clinical stigmata and detection of rubella on specific-HI antibody levels, compatible with congenital rubella specimens obtained at times which do not permit us to rule out post-natal infection. In more than half of all cases the diagnosis was established on the basis of cri- 
Table 1. Prevalence of ICSA according to HLA-DR type in congenital rubella

\begin{tabular}{ll}
\hline HLA-DR Antigen & ICSA-positive patients \\
\hline 2 & 6 out of 19 \\
3 & 8 out of 30 \\
4 & 6 out of 28 \\
other & 8 out of 44 \\
Unknown & 7 out of 52 \\
\hline Total & 35 out of 173 \\
\hline
\end{tabular}

teria (1) or (2), 16\% and $41 \%$ respectively. No significant differences in the frequency of these diagnostic criteria were observed for children who are currently diabetic. Thirty children are clinically diabetic according to the criteria of the National Diabetes Data Group [6], 15 of whom are constantly insulin-dependent (eight boys and seven girls), and have had at least one episode of ketoacidosis; one girl has received insulin intermittently and the other 14 (five boys and nine girls) have grossly abnormal oral glucose tolerance with 10 out of 14 having total insulin levels during a 3 -h oral glucose tolerance test at least two standard errors below the mean for normal children of the same age $(161 \pm 9 \mathrm{mU} / \mathrm{l})$ [7]

\section{Typing of HLA antigens}

HLA-A, $-\mathrm{B}$ and $-\mathrm{C}$ antigens were tested with the contrast fluorescence test using 180 mono- or oligo-specific reagents able to recognize 65 HLA antigens [8]. The two-colour fluorescence test described by Van Rood et al. was used for the testing of HLA-DR antigens [9].

\section{Pancreatic islet cell antibodies}

Pancreatic islet cell surface or cytotoxic antibodies (ICSA) were measured using as targets both the rat insulinoma line RIN5f [10] and neonatal rat islets [11]. In this study both methods for ICSA gave similar results.

Anti-thyroid microsomal and anti-thyroglobulin antibodies were measured by our newly described enzyme-like immuno-sorbant assay (ELISA) technique using human thyroid tissue [12].

\section{Oral glucose tolerance tests}

Oral glucose tolerance tests were performed in the standard manner with patients receiving $1.75 \mathrm{~g}$ glucose $/ \mathrm{kg}$ of ideal body weight up to a maximum of $100 \mathrm{~g}$. Blood specimens were obtained at $0,30,60,120$ and $180 \mathrm{~min}$ and were used for measurement of plasma glucose by the glucose oxidase technique and for determination of serum insulin levels by immunoassay techniques. Total insulin levels are equal to the sum of the values at the five test points. Values $>200 \mathrm{mU} / 1$ were designated as hyperinsulinaemia and those $<140 \mathrm{mU} / 1$ as hypoinsulinaemia. Borderline and grossly abnormal glucose tolerance tests refer to those where the peak plasma glucose levels were $>8.8 \mathrm{mmol} / 1$ and $11.1 \mathrm{mmol} / 1$, respectively.

\section{Results}

\section{HLA antigens}

Twenty-six out of 30 diabetic children have now had complete HLA typing. HLA-DR3 or DR4 was present in $21(81 \%)$. Four have both HLA-DR3 and DR4 and two are DR3 homozygotes. Of the five not having either DR3 or DR4, two have B8 or B18 in combination with other DR alleles. Only one has HLA-B7, associated with DR4 and DR5, and DR2 is absent in all 15 totally insulin-dependent patients. If these 26 congenital rubella patients with diabetes are compared with 162 congenital rubella patients without diabetes and 163 control subjects in the New York City area, DR2 is significantly decreased, DR3 is significally increased and the small increase in DR4 is not statistically significant.

\section{ICSA and anti-thyroid antibodies}

The prevalence of ICSA in patients with congenital rubella according to their HLA antigen is summarized in Table 1. There was no significant difference in the prevalence rate according to specific DR antigens and the overall prevalence for ICSA was $20 \%$ versus $<4 \%$ in controls.

In the 15 Type 1 diabetic patients, whose mean duration of the disease is 12 years, $37 \%$ are still positive for ICSA. In the other 15 diabetic patients, 11 of whom are hypoinsulinaemic, $81 \%$ are positive and of the 17 congenital rubella patients with borderline glucose tolerance tests, eight of whom are hypoinsulinaemic, 53\% are positive.

ICSA have also been found in 9 out of 13 stored serial specimens obtained in four congenital rubella patients starting at birth; three of these subjects now have diabetes.

Thirty-four percent of the congenital rubella patients also have anti-microsomal or anti-thyroglobulin antibodies and their frequency is $88 \%$ (23 out of 26 ) in congenital rubella patients with positive ICSA.

\section{Discussion}

In the present investigations, we have demonstrated that the three major criteria associated with Type 1 diabetes, namely the HLA-DR3, DR4 association, the virtual absence of HLA-DR2, ICSA and hypoinsulinaem$\mathrm{ia}$, are also present in patients with the congenital rubella syndrome who develop diabetes. This increased frequency of DR3 and decreased frequency of DR2 have only been reported in Type 1 diabetes [13]. Menser et al. [2] have reported previously that $50 \%$ of their patients with both congenital rubella and diabetes had HLA-A8 (now B8), usually found in linkage disequilibrium with HLA-DR3. Nance's group [3] reported an increase in HLA-B15 and B40 in their patients, but our report is the first complete study of the DR antigens [14]. Nance's group [3,15] also reported that $24.5 \%$ of their deaf patients had anti-thyroid microsomal and 7.1\% had parietal cell antibodies. They were, however, unable to find cytoplasmic islet cell antibodies and did not look for ICSA. The significance of this failure is not clear since these authors did not study congenital rubella but merely deaf patients. Methodological problems may also have been involved. 
Since the prevalence of diabetes is so much higher among our congenital rubella patients than in the general population (at least $12.4 \%$ - 30 out of 242 - versus $0.2 \%$ [16], it may be assumed that the difference is caused either by an increase of the penetrance of the susceptibility genotype(s) or of the number of phenocopies or by both [14]. An important increase in the number of phenocopies (i.e. disease without genetic susceptibility) should have resulted in a substantial reduction in the strength of the HLA associations which is not noted. Thus, it is more likely that the severe intrauterine infection with the virus, rubella, could push the penetrance of the common Type 1 diabetic-suspectibility genotype towards $100 \%$ [17]. Thus, our cohort of congenital rubella patients are an identifiable group in whom we can advantageously study immunological mechanisms operative prior to the development of diabetes, including the roles of subsets of T-lymphocytes and of the ICSA. Such studies could then provide a rational basis for intervention protocols aimed at reducing the expression of this severe disease and its host of long-term complications in other, and perhaps all settings.

Acknowledgements. Supported in part by March of Dimes-Birth Defects Foundation Grant No 6-358, NIH Grant No AM19631 and a grant from the American Diabetes Association. We thank the National Diabetes Research Interchange for providing human tissue.

\section{References}

1. Hay DR (1949) The relation of maternal rubella to congenital deafness and other abnormalities in New Zealand. NZ Med J 48: 604-608

2. Menser MA, Forrest JM, Honeyman MC, Burgess JA (1974) Diabetes, HLA-antigens and congenital rubella. Lancet 2: 1508-1509

3. Shaver KA, Boughman JA, Lovinger RD, Monhanakumar T, Nance WE (1982) Glucose intolerance and HLA antigens in the congenital rubella syndrome. Diabetes 31 (Suppl 2): 97A

4. Naeye RL, Blanc W (1965) Pathogenesis of congenital rubella. JAMA 194: 109-115

5. Rayfield EJ, Seto Y (1978) Viruses and the pathogenesis of diabetes mellitus. Diabetes 27: 1126-1140
6. National Diabetes Data Group (1979) Classification and diagnosis of diabetes mellitus and other categories of glucose intolerance. Diabetes 28: 1039-1057

7. Ginsberg-Fellner F, Dobersen MJ, Witt ME, Rayfield EJ, Rubinstein P, Notkins AL (1982) HLA antigens, cytoplasmic islet cell antibodies and carbohydrate tolerance in families of children with insulin-dependent diabetes mellitus. Diabetes 31: 292-298

8. Martel JL, Jaramillo S, Allen FH Jr, Rubinstin P (1974) Serology for automated cytotoxicity assay: contrast fluorescence test. Vox Sang 27: 13-20

9. Van Rood JJ, Van Leeuwen A, Ploehm SS (1976) Simultaneous detection of two cell populations by two-colour fluorescence and application to the recognition of B-cell determinants. Nature 262: 795-797

10. Toguchi Y, Ginsberg-Fellner F, Rubinstein P (1983) Islet cell surface antibodies (ICSA) in patients with insulin-dependent diabetes and their first degree relatives: a study of 112 families. Diabetes 32 (Suppl 1): $150 \mathrm{~A}$

11. Dobersen MJ, Scharff JE, Ginsberg-Fellner F, Notkins AL (1980) Cytotoxic autoantibodies to beta cells in the serum of patients with insulin-dependent diabetes mellitus. $\mathrm{N}$ Engl J Med 303: 1493-1498

12. Roman SH, Kovn F, Davies TF (1984) Enzyme-linked immunosorbent microassay and hemagglutination compared for detection of thyroglobulin and thyroid microsomal autoantibodies. Clin Chem 30: 246-250

13. Svejgaard A, Platz R, Ryder LP (1980) Insulin-dependent diabetes mellitus (Joint Report). In: Terasaki PI (ed) Histocompatability testing 1980. UCLA Tissue Typing Laboratory, Los Angeles, pp 638-656

14. Rubinstein P, Walker ME, Fedun B, Witt ME, Cooper LZ, Ginsberg-Fellner F (1982) The HLA system in congenital rubella patients with and without diabetes. Diabetes 31: 1088-1091

15. Bright GM, Clarke W, Kaiser D, Shaver K, Nance W (1982) Islet cell and other endocrine autoantibodies in congenital rubella. Diabetes 31 (Suppl 2): 101A

16. Kyllo CJ, Nuttall FQ (1978) Prevalence of diabetes mellitus in school-age children in Minnesota. Diabetes 27:57-60

17. Rubinstein P, Ginsberg-Fellner F, Falk C (1981) Genetics of Type 1 diabetes mellitus: a single recessive predisposition gene mapping between HLA-B and GLO. Am J Hum Genet 33: $865-882$

Dr. F. Ginsberg-Fellner

Division of Pediatric Endocrinology and Metabolism

Department of Pediatrics

Mount Sinai School of Medicine

1 Gustave L. Levy Place

New York NY 10029

USA 